\title{
Social support through religion and psychological well-being: COVID-19 and coping strategies in Indonesia
}

\author{
Muhammad Saud ${ }^{1}$ (D) . Asia Ashfaq ${ }^{2}$ - Ansar Abbas ${ }^{3}$. Septi Ariadi ${ }^{1}$. \\ Qaisar Khalid Mahmood ${ }^{4}$
}

Accepted: 26 March 2021 / Published online: 10 July 2021

(c) The Author(s), under exclusive licence to Springer Science+Business Media, LLC, part of Springer Nature 2021

\begin{abstract}
The Coronavirus pandemic (COVID-19) originated in China at the end of 2019, the virus festered there for four months before spreading globally. Impacting the developed and developing world including Indonesia. It has transformed social, economic and political practices social life, everyday habits and government policies, with multi-dimensional consequences on human life. The present study endeavours to explore the relationship between religiosity, social capital, and psychological well-being of the general public, particularly in terms of coping with the pandemic. In addition to this, the study aims to highlight the importance of public awareness regarding social distancing, use of religion as a coping mechanism, and living a healthy lifestyle during pandemic. For knowing the perception of the masses, an online survey by using a self-administered questionnaire was carried out among coronavirus patients, the general public, social media activists, students, and professionals across Indonesia. The findings indicate that the pandemic has altered the lifestyle of the masses in different ways and that people have varied perceptions towards this virus regarding its spread and preventive measures. The study also reveals that, social capital $(\beta=.418, \mathrm{p}<.001)$, psychological well-being $(\beta=.343, \mathrm{p}<.001)$, and religious coping $(\beta=.145, \mathrm{p}<.01)$ have a significant amount of the variance of coronavirus situational stress $(\mathrm{F}=69.77, \mathrm{p}<.001, \mathrm{R} 2=0.485)$. Lastly, the study suggests that, adopting preventative measures, standard operating procedures that are sustainable and healthy forms of coping with the pandemic will be equally as important as medical care in order to contain and eventually eradicate the virus.
\end{abstract}

Keywords COVID-19 $\cdot$ Religious $\cdot$ Spiritual coping $\cdot$ Social distancing · Quarantine $\cdot$ Pandemic $\cdot$ Indonesia

Muhammad Saud

muhhammad.saud@gmail.com

Extended author information available on the last page of the article 


\section{Introduction}

The spread of COVID-19 has been alarming and has affected nearly every community around the globe in an unprecedented way. Whatever humankind has achieved in the name of development; seems to have been affected during the pandemic such as human suffering, particularly vulnerable and marginalised communities. It is wreaking unfathomed sickness, and high death tolls which has exacerbated existing global issues. The current situation has not only affected how people interact, their lifestyles and social relationships but has also created predicaments in utilising cognitive abilities, availing knowledge and meeting goals due to the strain caused by COVID-19. The approaches, models, thoughts, and paradigms of recent events has exposed the inability of existing infrastructure to respond to the situation effectively. The development and advancement in human thoughts are influenced by multiple factors specifically philosophy, science and technology, belief and ideology and these need to be revamped constantly to keep human life in order. However, time invites humanity to ponder over this pandemic as a whistle-blower for those who have lived for worldly pursuits, ignoring the spiritual side of human existence.

As a result, if the illness and death rates of this virus remain high, then how will communities respond and protect themselves? Will the closing of roads, streets, mosques, churches, official buildings, universities, schools or offices, travel restrictions, and communitylevel quarantine be a substantial solution? Within society, this virus spreads from person to person through physical contact. Therefore, it is essential that standard operating procedures should be introduced, such as public awareness for minimizing social interaction during this crucial period of the COVID-19 pandemic. The current study aims to know the perception of the masses with regard to seeking social support through psychological well-being, religion and coping strategies for minimizing the transmission and effects of the virus.

\section{Psychological Well-Being}

According to Diener and Chan (2011), psychological well-being is an evaluation of one's life, including an assessment of life satisfaction and mood or emotions (Diener et al., 2011). It consists of two components i.e. emotional well-being and cognitive well-being. Emotional well-being is defined as the frequency of experiencing positive emotions by individuals more, as compared to that of negative emotions while the latter is defined as a general evaluation of the life satisfaction of a person (Marcionettiet \& Rossier, 2016). Along with multiple causes and effects, mental health is one of the significant facets of human life which needs to be given due attention in the current challenging times of the COVID-19 pandemic. In addition, mental health experts are playing a significant role in this regard and guiding the public of all ages to combat with mental health issues (CDCP, 2020).

Preventative measures have been offered by experts from distinct fields, such as healthcare professionals, psychologists, sociologists, community workers, and health practitioners to cope with the effects of the pandemic with a primary focus on protecting people from the virus and controlling its spread worldwide. For this purpose, 
different techniques for coping up with stress, anxiety, fear, depression, and other psychosocial problems are being disseminated among affected people during this time of social disruption. In this regard, few researches have specified that infectious diseases, such as Severe Acute Respiratory Syndrome (SARS), can bring people towards posttraumatic disorder, anxiety, stress, and depression (Hawryluck et al., 2004; Wu et al., 2005, 2008).

\section{COVID-19 and Religiosity}

Religiosity is a factor that is involved in the management of health, even in today's modern world where it is considered that science has replaced the belief systems. Scientific research may overlook this notion, that people still have a strong belief in spiritual healing, in curing illness and diseases. Religious practices and beliefs are considered as a springboard for medical care and treatment (Corman et al., 2020). In addition, numerous researchers have found that spirituality and religiosity are directly associated with better health outcomes, life satisfaction, longevity, and happiness (Greeley et al., 2006; Haslam et al., 2018; Ironson et al., 2018).

People belonging to different religious groups have various coping strategies, from denial of the effect of this virus to healing practices such as the practice of cleanliness and teachings regarding adherence to self-isolation with the faith of caring others. The counterproductive attitude of religious communities has become one of the challenges in fighting against coronavirus. Even though governments are taking strict measures, such as closure of public places, including religious places as well. Among different factors, religious understanding is one of the reasons for making the pandemic difficult to combat. For instance, it is assumed as being God's will, the decision of giving and taking of life is in God's hands, and fear of this virus is a deviation from faith in God (Spiteri et al., 2020).

There have been many misconceptions and much misinformation disseminated on electronic, print and social media about remedies for COVID-19. Throughout the world, various responses have differed on the basis of their religious beliefs. For instance, India is one such example with its deep-rooted culture and local misconceptions and misinformation adding to the problem. For example information has been circulating on social and electronic media where public figures and government agencies are offering remedies through drinking of cow urine in particular, which is based on their religious leanings and obligations which has no scientific basis (Perera et al., 2020).

Spirituality plays a pertinent role in the lives of patients and formally adheres to a specific religion and belief. According to Bornet and others (2019), spiritual healers and health professionals, who help in building care plans offer a better understanding of the patient, lead to better shared decisions (empowerment), coping and potential suffering. This embedded model can be beneficial and provides a better mechanism to formulate collaborations with spiritual care providers and health professionals. Researches on religion and spirituality have constantly expanded and being discussed in many publications (Koenig, 2012; Weaver et al., 2006). In fact, scholars from outside of behavioural, social and health sciences are familiar and 
engaged in religion and spiritual studies (Kim, et al., 2020). Spiritual wellbeing focuses on peace, stability and an intimate relationship with yourself and God, signifies two existential and religious dimensions. The existential health is concerned with searching for meaning of life and learning how to achieve perfection, whereas religious health primarily is a commitment and attachment to a religious belief (Villani, et al., 2019; Kord, et al., 2019). Therefore, the full integration of physical, mental, social and spiritual aspects of life endorses peace of mind and creates a sense of wholeness and well-being (Lifshitz, et al., 2019). It has been reported in media regarding the information about the treatment for this virus, suggesting engagement in spiritual and religious practices such as visiting churches, and offering prayers in mosques can protect people from the virus (Kowalczyk, et al., 2020).

Spiritual healing is also one of the methods in complementary and alternative medicines. According to Bornet and others (2019), spirituality is the belief that there is a greater power beyond the environment of human reach as well as other dimensions, such as purpose, the meaning of life, awareness of personal resources and the deepest feelings, personal integrity or connectedness. The scopes of spirituality consist of three dimensions (Kim et al., 2020), namely the meaning of life reflects the meaningfulness of life or the purpose of one's life. Peace is an effective aspect of one's spirituality and beliefs, including the individual's feelings of comfort that come from connecting with something broader than the human self (Kord et al., 2019; Lifshitz, et al., 2019). It has been reported through the media that information is being spread regarding a cure for this virus, saying that engaging in spiritual practices, such as visiting a church, and offering prayers can supposedly protect people, while the world sees things differently (Lv, et al., 2020).

\section{Social Capital}

Social support is exceptionally important for maintaining good social and physical health. Overall, it is found that, social support of high quality can help and protect against trauma, situational stress, and reduce morbidity and mortality (Ozbay et al., 2007). During this pandemic (COVID-19), it has been observed that people are trying to support others by sharing material online that may offer comfort. Social support as a protective stress process eliminates or reduces the effects of stress experiences through the use of effective coping strategies and a diminution in the interpretation of an event to reduce panic-related stress (Cohen, 2004).

In the present situation of the outbreak, creating awareness has become pertinent in order to give knowledge to the people for avoiding the infection through the COVID-19 virus. It is essential for community health and the safety of the public to take preventive measures on which public health has been focusing throughout the course of several years. In addition, people across the globe including developed and developing countries needs advocacy, awareness, appropriate knowledge about the spread of disease particularly the infected people and vulnerable communities. The current scenario in Indonesia and other countries demands socializing the masses for the provision of awareness. The primary benefits of socialization during such pandemics are knowing the information, control of social distancing, stay-at-home 
strategy, and coping with the challenge of the outbreak. In the wake of the spread of coronavirus in Indonesia, experts are urging people to limit their physical activities and contacts. As with other developed and developing countries, the government of Indonesia has also announced a partial lockdown to reduce physical interaction (Olivia et al., 2020).

This research article tends to know different dimensions of the outbreak of Coronavirus, including its spread, the ways to combat this virus and, more importantly, viewing the social perspective by focusing on the vulnerabilities of people. The study specifically highlights the influence of belief systems, the role of social capital, and the importance of people's mental health with regard to the current outbreak. Moreover, the aim of this study is to investigate and highlight social capital and religiosity and their effectiveness for combatting the pandemic. The authors belong to and reside in Surabaya, Indonesia where a greater number of people are infected by the virus and have been diagnosed with COVID-19 positive. Awareness campaigns through social media, print media, and other electronic media have been raised to urge the general masses to 'stay at home' and to reduce 'physical interaction'. This is a fact that the virus has affected every arena of life across the globe including the economy, education, service sectors, tourism, cross border movement, and many others for avoiding the situation getting worsen. Despite this, people are not staying at home and are regularly moving around such as local markets and streets; increasing the chances of making them more prone to be infected by the virus.

The awareness for safety measures from the current outbreak through social campaigns is a good strategy in reducing public anxiety and endorses government policy on social distancing. The current study was started with a global social survey by sending links to academicians, students, and the public living in Indonesia, Pakistan, and other countries. This research is unique in terms of its originality as it is focusing the issue which is prevailing around the globe and has affected people beyond borders and boundaries. Furthermore, it highlights the crucial aspects of COVID-19 such as threatening human safety and a healthy lifestyle, reducing social interaction/ social distancing, exploring the role of religion and coping strategies for minimizing its impact through social support, psychological well-being and religious belief systems.

\section{Literature Review}

COVID-19 is a pandemic on which sufficient literature is still not available and little can be said with absolute certainty so far based on scientific inquiry as investigations are still undergoing. This particular coronavirus pandemic is being investigated for the first time in world history (Koonin, 2020). The impact of coronavirus has been devastating. For example, it has been estimated that well over a hundred million people have been infected, with approximately 3 million deaths globally, but on the other hand, over 75 million people have recovered through different treatments (DW reports, 2020). The World Health Organization (WHO, 2019) declared that there was a lack of availability and/or accessibility of a vaccine against COVID-19 
till late 2020 . The only remedy initially was to reduce travel, limit social interaction, and enforce social distancing and still is supposed to be practiced. Coronavirus poses a serious threat by evolving into a global pandemic (Anjum et al., 2020; Tamrat \& Teferra, 2020) with the fact about its rapid transmission from one infected person to others during their interaction and the extent of the contagion in a larger population (WHO, 2019).Previous studies support the idea that religion, spirituality, and health have grown over recent decades (Hall, et al., 2004). Basic religiosity measures are associated with positive mental and bodily health outcomes (Koeing et al., 2012; Pargament, 2013). In addition to this, another research has shown a positive relationship between health and religion (Bonelli \& Koenig, 2013). The findings of the international social survey program indicate that an individual's spiritual experiences are more important than belonging to a formal religious institution (Vaccarino, et al., 2011). This illustrates that, due to this outbreak, people were asked by the governments to offer their religious practices at home, recognizing that congregation for religious practices may increase the risk of spread of the virus while gathering people in enclosed spaces can be possible without having physical interaction. This recommendation by governments was endorsed by the citizens such as in New Zealand, religious communities stand united with the state in reducing religious gatherings (Oxholm, et al., 2021; Hvidt et al., 2017) so that the spread of the virus may be controlled. Furthermore, social capital and social support are the best strategies to cope up with the outbreak and transmission among humans (Song, et al., 2009).

Psychological wellbeing and social support have a positive relationship, which can result in a positive outcome in the recovery of patients. Social support is further divided into emotional, instrumental, information support, and social companionship (Weiss, 1974; Cohenet \& Wills, 1985). Emotional support is the provision of empathy, trust, and caring, while instrumental supports are practical in use. Information support is the provision of advice or solutions to problems, and companionship involves spending social or leisure time with others. However, these days, people are more active on social media, the Internet, or telecommunication devices to communicate with their families, share valuable information, and suggest remedies for the cure (Saud, et al., 2020). Recently, there has been a particular focus of public health on the significance of social capital in finding better healthcare i.e. people with restricted networks have poorer health indicators while higher social support has a positive impact on mental health (Mitchell, et al., 2002; Ferlander, 2007).

The control of the spread of the Coronavirus is challenging due to the limited availability of medical treatment for this particular virus, while scientists continue to research and learn about the infection and how it mutates. Different guidelines (Standard Operating Procedures: SoPs) are suggested for its control, such as wearing of masks, maintaining distance, certified cleaning material, washing hands regularly, self-quarantining, travel restrictions. Previous studies regarding pandemics have asserted that university or school closures during pandemics can reduce chances of infection (Cauchemez et al., 2014). In addition, other studies from 19571958 discuss the outbreak of the Asian flu, suggesting that social distancingand reducing social interaction, closure of religious institutions, can also mitigate the localized progression of pandemics without the use of medicines (Glass et al., 2006). While 
The World Health Organization (WHO) and other international organisations assist states and governments with the production of a COVID-19 vaccine, it is necessary to take measures to study and collect data that is cross-sectional and representative of varying experiences and mitigation procedures taken globally to effectively contain the virus and prevent further outbreaks. The purpose of this survey is to educate, rehabilitate affected patients, and provide information about pandemics to the general public globally. To combat general ignorance and neglect with regards to adapting and mitigating the virus within the general public, social scientists research advocate and advise for social safety measures. Indeed, to cope up with pandemics, this survey is useful in accessing public opinion and people's perception. Thus, the current study aims to highlight and analyse the role of psychological well-being, religiosity and social capital in responding to COVID-19.

COVID-19 is a pandemic on which sufficient literature is still not available and nothing can be said so far based on scientific inquiry as the investigation is undergoing. Coronavirus pandemics is being investigated for the first time in world history (Koonin, 2020; Yee et al., 2020). The impact of Coronavirus has been devastating For example, it has been estimated that over half a million people have been infected, with over 24,000 deaths globally, but on the other hand, 123,000 people have recovered from it through different measures (Al Jazeera, 2020). The World Health Organization (WHO, 2019) also declared the non-availability of a vaccine against COVID-19 and, in a press conference conducted by Mike Ryan (WHO representative), it was stated that a 'Coronavirus vaccine is a year away'. The only remedy is to reduce travel, social interaction, and social distancing. Other statistics estimate the number of affected people at around 400,000 people worldwide.

Coronavirus represents a serious threat, evolving into a human pandemic (Cascella, et al, 2020; Wise et al., 2020). The possibility is that this virus may transmute

Table 1 Socio-demographic variables

\begin{tabular}{llccc}
\hline Variable name & Value & Frequency & Percentage & Cumulative \% \\
\hline \multirow{2}{*}{ Age } & $18-30$ & 169 & 76.8 & 76.8 \\
& $31-40$ & 37 & 16.8 & 93.6 \\
\multirow{5}{*}{ Religion } & 40 or above & 14 & 6.4 & 100 \\
& Islam & 202 & 91.8 & 91.8 \\
& Christian & 8 & 3.6 & 95.5 \\
& Buddhist & 1 & 0.5 & 95.9 \\
& Hindu & 2 & 0.9 & 96.8 \\
\multirow{5}{*}{ Education } & Do not believe or practice religion & 7 & 3.2 & 100 \\
& Bachelor & 93 & 42.3 & 42.3 \\
& Masters & 95 & 43.2 & 85.5 \\
& PhD & 22 & 10 & 95.5 \\
Gender & Other degree or diploma & 10 & 4.5 & 100 \\
& Male & 153 & 69.5 & 69.5 \\
& Female & 67 & 30.5 & 100 \\
& Total & 220 & 100 & \\
\hline
\end{tabular}


Table 2 Mean and standard deviation between religiosity, social capital, and coping strategies

\begin{tabular}{llllllllc}
\hline Statistics & \multicolumn{1}{l}{ Age } & Religion & Education & Gender & SC $^{\mathrm{a}}$ & PSYWB $^{\mathrm{a}}$ & RC $^{\mathrm{a}}$ & SS $^{\mathrm{a}}$ \\
\hline$N=220$ & 1.30 & 1.20 & 1.77 & 1.30 & 24.82 & 22.69 & 20.99 & 45.05 \\
Mean & 0.039 & 0.053 & 0.055 & 0.031 & 0.396 & 0.353 & 0.319 & 0.507 \\
Std. Error of Mean & 1.00 & 1.00 & 2.00 & 1.00 & 25.50 & 24.29 & 21.67 & 47.08 \\
Median & 0.58 & 0.78 & 0.81 & 0.46 & 5.88 & 5.24 & 4.73 & 7.52 \\
Std. Deviation & & &
\end{tabular}

${ }^{\text {a }}$ SC, (Social Capital), PSYWB (Psychological Well-being), RC (Religious coping), SS (Coronavirus Situational Stress)

Table 3 Correlations

\begin{tabular}{|c|c|c|c|c|c|c|c|}
\hline \multicolumn{2}{|c|}{ Variable description } & \multirow[t]{2}{*}{1} & \multirow[t]{2}{*}{2} & \multirow[t]{2}{*}{3} & \multirow[t]{2}{*}{4} & \multirow[t]{2}{*}{5} & \multirow[t]{2}{*}{6} \\
\hline 1 & Age & & & & & & \\
\hline 2 & Educational level & $.312 * *$ & 1 & & & & \\
\hline 3 & Social capital & -0.006 & 0.042 & 1 & & & \\
\hline 4 & Psychological well-being & -0.018 & $.150^{*}$ & $.611 * *$ & 1 & & \\
\hline 5 & Religious coping & -0.023 & 0.061 & 0.01 & 0.024 & 1 & \\
\hline 6 & Situational stress & -0.046 & $.156^{*}$ & $.629 * *$ & $.602 * *$ & $.158^{*}$ & 1 \\
\hline
\end{tabular}

** Correlation is significant at the 0.01 level (2-tailed)

* Correlation is significant at the 0.05 level (2-tailed)

or espouse to increase efficient transmission in humans during the co-infection of a single host, resulting in it spreading to the general public. According to studies, there is a strong possibility of transmission of such viruses by human interaction (Jung et al., 2020). Therefore, reducing the chance of being infected with Coronavirus can only be achieved through social distancing and minimum social interaction within the community.

Previous studies support the idea that religion, spirituality, and health have grown exclusively over recent decades (Hall, et al., 2004). Basic religiosity measures are associated with positive mental and bodily health outcomes (Koeing et al., 2012; Pargament, 2013). In addition to this, the majority of the studies (72\%) have shown a positive relationship between health and religion, and only sixteen per cent have reported a negative opinion (Bonelli et al., 2013). The findings of the international social survey program indicate that an individual's spiritual experiences are more important than belonging to a formal religious institution (Vaccarino, et al., 2011). This illustrates that due to this outbreak, governments put lockdowns and people were asked to offer their religious practices at home, recognizing that religious practices as individual state of affairs and can be done with having physical interaction. Similarly, in New Zealand, religious communities stand united and in agreement with the state in reducing religious gatherings (Oxholm, et al., 2021; Hvidt et al., 2017). Furthermore, social capital and social support are the best strategies to cope with the outbreak and transmission among humans (Song, et al., 2009). 
Psychological well-being and social support have a positive relationship, which can result in a positive outcome in the recovery of patients. Social support is further divided into emotional, instrumental, information support, and social companionship (Cohenet al., 1985; Weiss, 1974). Emotional support is the provision of empathy, trust, and caring, while instrumental supports are practical in helping. Information support is the provision of advice or solutions to problems, and companionship involves spending social or leisure time with others. However, these days, people are more active on social media, the Internet, or telecommunication devices to communicate with their families, share valuable information, and suggest remedies for the cure (Saud, et al., 2020). Recently, there has been a particular focus on the significance of cross-cutting, bridging, and linkages social capital for the health finding that membership of more restricted networks is associated with poorer self-related health, and has a positive impact on mental health (Ferlander, 2007; Mitchell et al., 2002).

Due to the limited effectiveness of medicines, in controlling the spread of the Coronavirus, various other non-pharmaceutical interventions (NPIs) are being suggested by the practitioners. These include the use of masks, washing hands regularly, proper cleaning materials, social distancing, or self-quarantining, travel restrictions and isolation. According to the model of mitigation strategies, university or school closures during such pandemics can reduce the chances of infection by around forty per cent (Germann et al., 2006). In addition, other studies from 1957-1958 discuss the outbreak of Asian flu, suggesting that social distancing and reducing social interaction, such as the closure of religious buildings, can also mitigate the localized progression of pandemics without the use of medicines (Glass et al., 2006). The World Health Organization (WHO) and other international organizations are helping states and governments with the production of a COVID-19 vaccine, and there is a need to start a global survey of public awareness and knowledge to control further outbreaks in society. The purpose of the social survey is to educate, build the capacity of affected patients, and provide information about pandemics to the general public globally. Usually, the general public is unaware of these viral infections and, during these crises, it is the duty of social scientists to teach and prepare material for social safety information. Indeed, to cope with pandemics, this social survey is useful in accessing public opinion and people's perceptions. The present study shows that it is a grim requirement to socialize people through a social survey on non-pharmaceutical interventions (NPIs) that can socialize people to people, and which may reduce the chances of an outbreak of such pandemics.

\section{Materials and Methods}

The current study entails a quantitative research design to collect data from Coronavirus patients, the general public, social media activists, students, and professionals across multiple countries, namely: Indonesia, Gambia, Uganda, Pakistan, Malaysia, and Madagascar. The researcher invited respondents through Google forms, WhatsApp, Facebook, and other social media applications for submission of their responses online keeping in view time, cost and physical interaction constraints. A 
Table 4 Stepwise multiple linear regression analysis

\begin{tabular}{|c|c|c|c|c|c|c|c|}
\hline \multirow{2}{*}{$\begin{array}{l}R \\
629 \mathrm{a}\end{array}$} & \multirow{2}{*}{$\begin{array}{l}R \text { Square } \\
0.395\end{array}$} & \multirow{2}{*}{$\begin{array}{l}\text { Adjusted } R \text { square } \\
0.393\end{array}$} & \multicolumn{2}{|c|}{ Std. Error of the Estimate } & \multirow[t]{2}{*}{ Beta } & \multirow{2}{*}{$\frac{t}{14.597}$} & \multirow{2}{*}{$\frac{\mathrm{Sig}}{0.000}$} \\
\hline & & & 5.85911 & (Constant) & & & \\
\hline & & & & Social Capital & 0.629 & 11.942 & 0.000 \\
\hline \multirow[t]{3}{*}{$.686 b$} & 0.471 & 0.466 & 5.49305 & (Constant) & & 11.352 & 0.000 \\
\hline & & & & Social Capital & 0.417 & 6.679 & 0.000 \\
\hline & & & & Psychological Well-being & 0.347 & 5.570 & 0.000 \\
\hline \multirow[t]{4}{*}{$.702 \mathrm{c}$} & 0.492 & 0.485 & 5.39508 & (Constant) & & 6.627 & 0.000 \\
\hline & & & & Social Capital & 0.418 & 6.818 & 0.000 \\
\hline & & & & Psychological Well-being & 0.343 & 5.601 & 0.000 \\
\hline & & & & Religious Coping & 0.145 & 2.992 & 0.003 \\
\hline
\end{tabular}

b ANOVA

\begin{tabular}{|c|c|c|c|c|c|c|}
\hline \multicolumn{7}{|c|}{ ANOVA (a) } \\
\hline Model & & Sum of Squares & $d f$ & Mean Square & $F$ & Sig. \\
\hline \multirow[t]{3}{*}{1} & Regression & 4895.674 & 1 & 4895.674 & 142.61 & $.000 \mathrm{~b}$ \\
\hline & Residual & 7483.758 & 218 & 34.329 & & \\
\hline & Total & 12379.43 & 219 & & & \\
\hline \multirow[t]{3}{*}{2} & Regression & 5831.759 & 2 & 2915.88 & 96.637 & $.000 \mathrm{c}$ \\
\hline & Residual & 6547.673 & 217 & 30.174 & & \\
\hline & Total & 12379.43 & 219 & & & \\
\hline \multirow[t]{3}{*}{3} & Regression & 6092.341 & 3 & 2030.78 & 69.77 & $.000 \mathrm{~d}$ \\
\hline & Residual & 6287.092 & 216 & 29.107 & & \\
\hline & Total & 12379.43 & 219 & & & \\
\hline
\end{tabular}

${ }^{a}$ Dependent Variable: Coronavirus Situational Stress

${ }^{b}$ Predictors: (Constant), Social Capital

${ }^{\mathrm{c}}$ Predictors: (Constant), Social Capital, Psychological Well-being

${ }^{\mathrm{d} P r e d i c t o r s: ~(C o n s t a n t), ~ S o c i a l ~ C a p i t a l, ~ P s y c h o l o g i c a l ~ W e l l-b e i n g, ~ R e l i g i o u s ~ C o p i n g ~}$

self-administered questionnaire was designed to investigate the respondents' views about, religiosity, psychological well-being, social support, social capital and coping strategies for combatting with the current pandemic.

The research instrument (added in the supplementary) was designed according to the objectives of the present study such as socio-economic and demographic characteristics, corona effects, and knowledge of the virus, eating habits, losing social capital, level of social distancing, religious coping strategies and social support. Before asking the respondents to fill out survey forms, technical information regarding the COVID-19 virus was provided for their knowledge and awareness. The procedure for this data ensured the ethical consideration, documentation of the enumerators, researchers, or respondents, and informed consent was obtained before the start of this study. The data collection commenced at the start of February 2020, and was completed in April, 2020. A total of 221 completed the survey, but due to missing data reported, only 220 proved valid for the data analysis. The data was further 
organised in Microsoft excel, coded in the SPSS-26 and analysed into the univariate and bivariate analysis.

\section{Statistical Analysis}

The data was gathered through an online survey and analysed by using SPSS. Both univariate and bivariate analysis were done where frequency distribution was presented in tabular form and regression was run respectively.

\section{Result and Analysis}

Table 1 shows the socio-demographic status of the respondents. Out of the 220 respondents, the majority were male $(69.5 \%, n=153)$ and little less than half of the respondents $(42.3 \%, n=93)$ reported their educational qualification as a graduate. More than three-quarters of the respondents $(76.8 \%, n=169)$ were $18-30$ years old, whereas there was only a $6.4 \%$ per cent $(n=14)$ respondent who was 40 years old and above. In this study, an overwhelming majority $(91.8 \%, n=202)$ were Muslims and 18 respondents belonged to other religions. We contacted the respondents by way of social media and other personal sources, and people participated from diverse backgrounds.

Table 2 summarizes the mean and standard deviation of the construct used to measure religious coping, social capital, psychological well-being, and perceived Coronavirus situational stress in recent times. Studies endorse the fact that positive religious coping has frequently been associated with better mental health when dealing with stressful events, such as natural disasters, pandemics, abuses, and others (Thomas et al., 2020). The connection between depression and religiosity highlights a possible mechanism that might play an important role. Religious and spiritual practices may affect the physical changes in the brain and can increase the neurotransmitter serotonin (Newberg, 2011). According to the results given in Table 2, it can be seen that demographic variables range from 1.20 to 1.77 . This indicates that this pandemic undoubtedly represents a significant stressor for many individuals around the globe. Furthermore, other constructs range between 20.00 and 45.5, and a higher rank of Coronavirus situational stress was reported.

Table 3 describes a correlational analysis of the study variables. The findings show that the social capital of the respondents is strongly correlated with psychological well-being $(r=0.611, p<0.01)$ and situational stress $(r=0.629, p<0.01)$. Psychological well-being also has a strong and positive correlation with situational stress $(r=0.602, p<0.01)$. The educational level of the respondents is associated with age $(r=0.312, p<0.01)$, psychological well-being $(r=0.150, p<0.01)$, and situational stress $(r=0.156, p<0.05)$. It is also found that religious coping has a statistically significant relationship with situational stress $(r=0.158, p<0.01)$ as well. Data from other nations shows that after the government's lockdown restrictions placed on freedom of movement, the level of depression and anxiety was much higher than those observed in pre-community surveys (Li et al., 2020; Qureshi, 
et al., 2020), and it raised the importance of religious coping and social support in reducing the circumstances among humans. This pandemic presents an opportunity to further explore the links between religious coping and social support versus psychological well-being. The widespread nature of the outbreak also allows us to simultaneously explore similarities and differences in coping through social support, social capital, and religion.

A stepwise multiple linear regression (Table 4) was performed to explain the variance of coronavirus situational stress. The findings confirm that social capital is a major predictor to explaining Coronavirus situational stress $(F=142.61, p<.001$, $\beta=.629, R 2=.393)$. Supporting these results, a previous study found that individuals with greater social capital have better health outcomes (Chen et al., 2015), which encourages them to invest in social capital. A second predictor is a psychological well-being. In the second model, both variables explain a forty-six percent variance of Coronavirus situational stress. Therefore, connecting people through online spheres could be helpful in enhancing psychological well-being (Bano et al., 2019) via bonding capital and a high presence of social integration. A third variable is religious coping. In model three, social capital $(\beta=.418, p<.001)$, psychological well-being $(\beta=.343, p<.001)$ and religious coping $(\beta=.145, p<.01)$ explain a significant amount of the variance of Coronavirus situational stress $(F=69.77, p<$ $.001, R 2=0.485$ ). Furthermore, religious coping, social capital, and social support mental health considering this pandemic has resulted in people taking on a multifaceted approach to cope with the virus.

\section{Discussion}

This study is a unique attempt to explore the social support, social capital, psychological well-being and religious coping strategies for pandemic situations. The present study aims to develop and investigate religiosity, social capital, psychological well-being, and religious coping. The quantitative analysis highlights two major findings. First, during this pandemic, due to religious and social support people are likely to adopt religious practices either in Islam or Christianity, Hinduism, Buddhist or to have no faith. The stepwise multiple linear regression shows that social capital is a major predictor to explaining Coronavirus situational stress $(F=142.61$, $p<0.001, \beta=0.629, R 2=0.393$ ). A study conducted by Mandelbaum and colleagues (2018) found that the stress-buffering hypothesis suggests that people with social resources may support reducing or preventing the impact of stress on health (Cohen et al., 1985; Mandelbaum et al., 2018). Other studies also show that individuals who have access to more social resources, such as social support, have better health outcomes compared to others with less social resources (Baek, et al., 2014). Research on social capital and health frequently emphasizes the importance of weak ties and network diversity for better health conditions (Berkman, et al., 2000; Mooreet al., 2016). Therefore, social support and social capital are social resources, which help people during these pandemics days.

Psychological distress among people during pandemics is a global concern. Education is one of the most significant social indicators for socializing and providing 
awareness of public health issues. It is also a fundamental social determinant of health (Hahnet al., 2015). The results further show that education is also a key factor in helping individuals during these times. It is explained that the educational level of the respondent is associated with age $(r=0.312, p<0.01)$, psychological well-being $(r=0.150, p<0.01)$, and situational stress $(r=0.156, p<0.05)$. Psychological stress is associated with education, and its role of support is consistent in previous findings (Pryjmachuk et al., 2007). It is to support that logically a good education makes strong emotional and psychological well-being (Higgins, 2011).

From a conceptual and methodological perspective, coping is considered a mediating variable between social support and religion. It can be seen in a model tested in the results above with social capital $(\beta=0.418, p<0.001)$, psychological well-being $(\beta=0.343, p<0.001)$, and religious coping $(\beta=0.145, p<0.01)$ explaining a significant amount of the variance of Coronavirus situational stress $(F=69.77, p<0.001$, $R 2=0.485$ ). The field of positive psychology has focused on several areas of human functioning that are associated with healthy living, such as social support and religious coping (Salsman et al., 2005). Religious and social support factors have also generated considerable interest and have been associated with better physical and mental health outcomes. In conclusion, the result of the study adds social support, social capital, and religion to the emerging area of research on coping strategies during the outbreak of the COVID 19 pandemic worldwide.

\section{Conclusion}

This study summarizes the various mental, physical and emotional impacts that COVID has had and the various coping mechanisms that have been adopted to adjust to radical changes in daily lifestyles. In addition to its physical health implications, the pandemic has had numerous effects on psychological well-being, people's economic situations, and social relationships. This pandemic has altered the lifestyle of masses of people in different ways and people have varied perceptions towards this virus regarding its spread, diagnosis, and treatment. Adopting preventative measures, standard operating procedures that are sustainable and healthy forms of coping with the pandemic will be equally as important as medical care in order to contain and eventually eradicate the virus. In this regard, different factors, such as religiosity, psychological wellbeing, social support, and social capital have different influences. People belonging to various religious groups have several coping strategies that vary from wilful denial of the severity of the virus to seeking forms of being able to heal from it. The findings from the data reveal that there is a statistically significant and positive relationship between praying to God and a belief that the current situation is the outcome of God's will. The present study has certain limitations due to the lack of literature and authentic knowledge on this pandemic.

While this study was not representative of all religious faiths, and was dominated by Indonesian Islamic respondents, nevertheless, the results show that despite a lack of medical facilities during the pandemic, other remedies existed, such as, social support, and religiosity, all of which have potential effects on human psychological well-being. 
Supplementary Information The online version contains supplementary material available at https://doi. org/10.1007/s10943-021-01327-1.

Funding No funding was availed.

\section{Declaration}

Confict of interest The authors declare that they have no confict of interest.

Ethical Approval This study and participant questionnaire were designed and conducted by the mutual cooperation of external experts and the author research team from the Universitas Airlangga Indonesia, Bahria University Islamabad Pakistan, and the International Islamic University Islamabad, Pakistan. The authors and associated Universities take full ethical responsibility for this study.

Informed Consent Informed consent was acquired from all participants before commencing the survey.

\section{References}

Al Jazeera report (2020) Retrieved from [https://www.aljazeera.com/news/2020/03/million-infectedworldwide-deaths-surge-liveupdates-200326230320792.html]

Anjum, S., Ullah, R., Rana, M. S., Ali Khan, H., Memon, F. S., Ahmed, Y., Jabeen, S., \& Faryal, R. (2020). COVID-19 pandemic: A serious threat for public mental health globally. Psychiatria Danubina, 32(2), 245-250. https://doi.org/10.24869/psyd.2020.245.

Baek, R. N., Tanenbaum, M. L., \& Gonzalez, J. S. (2014). Diabetes burden and diabetes distress: The buffering effect of social support. Annals of Behavioral Medicine, 48(2), 145-155. https://doi.org/ 10.1007/s12160-013-9585-4

Bano, S., Cisheng, W., Khan, A. N., \& Khan, N. A. (2019). WhatsApp use and student's psychological well-being: Role of social capital and social integration. Children and Youth Services Review, 103, 200-208. https://doi.org/10.1016/j.childyouth.2019.06.002

Berkman, L. F., Glass, T., Brissette, I., \& Seeman, T. E. (2000). From social integration to health: Durkheim in the new millennium. Social Science \& Medicine, 51(6), 843-857. https://doi.org/10.1016/ s0277-9536(00)00065-4

Bonelli, R. M., \& Koenig, H. G. (2013). Mental disorders, religion and spirituality 1990 to 2010: A systematic evidence-based review. Journal of Religion and Health, 52(2), 657-673. https://doi.org/10. 1007/s10943-013-9691-4

Bornet, M. A., Edelmann, N., Rochat, E., Cornuz, J., Poncin, E., \& Monod, S. (2019). Spiritual care is stagnating in general practice: The need to move towards an embedded model. British Journal of General Practice, 69(678), 40-41. https://doi.org/10.3399/bjgp19X700613

Cascella, M., Rajnik, M., Cuomo, A., Dulebohn, S. C., \& Di Napoli, R. (2020). Features, evaluation and treatment coronavirus (COVID-19). StatPearls Publishing.

Cauchemez, S., Ferguson, N. M., Fox, A., Mai le, Q., Thanh le, T., Thai, P. Q., Thoang, D.D., Duong, T.N., Minh Hoa le, N., Tran Hien, N., Horby. P. (2014). Determinants of influenza transmission in South East Asia: insights from a household cohort study in Vietnam. PLoS pathogens, 10(8), e1004310

Centers for Disease Control and Prevention. (2020). National diabetes statistics report, 2020. Atlanta, GA: Centers for Disease Control and Prevention, US Department of Health and Human Services.

Chen, X., Wang, P., Wegner, R., Gong, J., Fang, X., \& Kaljee, L. (2015). Measuring social capital investment: Scale development and examination of links to social capital and perceived stress. Social Indicators Research, 120(3), 669-687. https://doi.org/10.1007/s11205-014-0611-0

Cohen, S. (2004). Social relationships and health. American Psychologist, 59(8), 676. https://doi.org/10. 1037/0003-066X.59.8.676

Cohen, S., \& Wills, T. A. (1985). Stress, social support, and the buffering hypothesis. Psychological Bulletin, 98(2), 310-357. https://doi.org/10.1037/0033-2909.98.2.310 
Corman, V. M., Landt, O., Kaiser, M., Molenkamp, R., Meijer, A., Chu, D. K., \& Mulders, D. G. (2020). Detection of 2019 novel coronavirus (2019-nCoV) by real-time RT-PCR. Eurosurveillance, 25(3), 2000045. https://doi.org/10.2807/1560-7917.ES.2020.25.3.2000045

Diener, E., \& Chan, M. Y. (2011). Happy people live longer: Subjective well-being contributes to health and longevity. Applied Psychology: Health and Well-Being, 3(1), 1-43. https://doi.org/10.1111/j. 1758-0854.2010.01045.x

DW News reports. (2020). Retrieved from https:/www.dw.com/en/coronavirus-latest-who-sayshealthworkers-account-for-10-of-global-infections/a-54208221

Ferlander, S. (2007). The importance of different forms of social capital for health. Acta Sociologica, 50(2), 115-128. https://doi.org/10.1177/0001699307077654

Germann, T. C., Kadau, K., Longini, I. M., \& Macken, C. A. (2006). Mitigation strategies for pandemic influenza in the United States. Proceedings of the National Academy of Sciences, 103(15), 59355940. https://doi.org/10.1073/pnas.0601266103

Glass, R. J., Glass, L. M., Beyeler, W. E., \& Min, H. J. (2006). Targeted social distancing designs for pandemic influenza. Emerging Infectious Diseases, 12(11), 1671. https://doi.org/10.3201/eid1211. 060255

Greeley, A. M., \& Hout, M. (2006). The truth about Conservative Christians: What they think and what they believe. University of Chicago Press.

Hahn, R. A., \& Truman, B. I. (2015). Education improves public health and promotes health equity. International Journal of Health Services, 45(4), 657-678. https://doi.org/10.1177/0020731415585986

Hall, D. E., Koenig, H. G., \& Meador, K. G. (2004). Conceptualizing" religion": How language shapes and constrains knowledge in the study of religion and health. Perspectives in Biology and Medicine, 47(3), 386-401. https://doi.org/10.1353/pbm.2004.0050

Haslam, C., Jetten, J., Cruwys, T., Dingle, G., \& Haslam, S. A. (2018). The new psychology of health: Unlocking the Social Cure. Routledge. https://doi.org/10.4324/9781315648569

Hawryluck, L., Gold, W. L., Robinson, S., Pogorski, S., Galea, S., \& Styra, R. (2004). SARS control and psychological effects of quarantine, Toronto, Canada. Emerging Infectious Diseases, 10(7), 1206. https://doi.org/10.3201/eid1007.030703

Higgins, C. (2011). The good life of teaching. An ethics of professional practice. Oxford, England: Willey-Blackwell. ISBN: 978-1-444-34651-0

Hvidt, N. C., Hvidtjørn, D., Christensen, K., Nielsen, J. B., \& Søndergaard, J. (2017). Faith moves mountains - mountains move faith: Two opposite epidemiological forces in research on religion and health. Journal of Religion and Health, 56(1), 294-304. https://doi.org/10.1007/s10943-016-0300-1

Ironson, G., Lucette, A., Hylton, E., Pargament, K. I., \& Krause, N. (2018). The relationship between religious and psych spiritual measures and an inflammation marker (CRP) in older adults experiencing life event stress. Journal of Religion and Health, 57(4), 1554-1566. https://doi.org/10.1007/ s10943-018-0600-8

Jung, S. M., Akhmetzhanov, A. R., Hayashi, K., Linton, N. M., Yang, Y., Yuan, B., \& Nishiura, H. (2020). Real-time estimation of the risk of death from novel coronavirus (COVID-19) infection: Inference using exported cases. Journal of Clinical Medicine, 9(2), 523. https://doi.org/10.3390/jcm9020523

Kim, S. H., Lee, N., \& King, P. E. (2020). Dimensions of religion and spirituality: A longitudinal topic modeling approach. Journal for the Scientific Study of Religion, 59(1), 62-83. https://doi.org/10. 1111/jssr.12639

Koenig, H., Koenig, H. G., King, D., \& Carson, V. B. (2012). Handbook of religion and health. Oup Usa.

Koonin, L. M. (2020). Novel coronavirus disease (COVID-19) outbreak: Now is the time to refresh pandemic plans. Journal of Business Continuity and Emergency Planning, 13(4), 1-15.

Kord, B., \& Biadar, S. (2019). Predictive role of spiritual well-being for optimism and life expectancy among women who referred to health centers. Health, Spirituality and Medical Ethics, 6(4), $23-28$. https://doi.org/10.29252/jhsme.6.4.23

Kowalczyk, O., Roszkowski, K., Montane, X., Pawliszak, W., Tylkowski, B., \& Bajek, A. (2020). Religion and Faith Perception in a Pandemic of COVID-19. Journal of religion and health, 59(6), 26712677. https://doi.org/10.1007/s10943-020-01088-3

Lei, L., Huang, X., Zhang, S., Yang, J., Yang, L., \& Xu, M. (2020). Comparison of prevalence and associated factors of anxiety and depression among people affected by versus people unaffected by quarantine during the COVID-19 epidemic in southwestern China. Medical Science Monitor: International Medical Journal of Experimental and Clinical Research, 26, e924609-1. https://doi.org/10. 12659/MSM.924609 
Lifshitz, R., Nimrod, G., \& Bachner, Y. G. (2019). Spirituality and wellbeing in later life: A multidimensional approach. Aging and Mental Health, 23(8), 984-991. https://doi.org/10.1080/13607863.2018. 1460743

Lv, M., Luo, X., Estill, J., Liu, Y., Ren, M., Wang, J., \& Feng, X. (2020). Coronavirus disease (COVID19): A scoping review. Eurosurveillance, 25(15), 2000125. https://doi.org/10.2807/1560-7917.ES. 2020.25.15.2000125

Mandelbaum, J., Moore, S., Silveira, P. P., Meaney, M. J., Levitan, R. D., \& Dubé, L. (2018). Does social capital moderate the association between children's emotional overeating and parental stress? A cross-sectional study of the stress-buffering hypothesis in a sample of mother-child dyads. Social Science and Medicine, . https://doi.org/10.1016/j.socscimed.2018.12.023

Marcionetti, J., \& Rossier, J. (2016). Global life satisfaction in adolescence: The role of personality traits, self-esteem, and self-efficacy. Journal of Individual Differences, 37(3), 135-144. https:// doi.org/10.1027/1614-0001/a000198

Mitchell, C. U., \& LaGory, M. (2002). Social capital and mental distress in an impoverished community. City and Community, 1(2), 199-222. https://doi.org/10.1111/1540-6040.00017

Moore, S., Teixeira, A., \& Stewart, S. (2016). Do age, psychosocial, and health characteristics alter the weak and strong tie composition of network diversity and core network size in urban adults? SSM-Population Health, 2, 623-631. https://doi.org/10.1016/j.ssmph.2016.08.009

Newberg, A. (2011). Transformation of brain structure and spiritual experience. In Handbook of Psychology and Spirituality. Edited by L. Miller. New York: Oxford University Press. https://doi. org/10.1093/oxfordhb/9780199729920.013.0031

Olivia, S., Gibson, J., \& Nasrudin, R. A. (2020). Indonesia in the time of Covid-19. Bulletin of IndonesianEconomic Studies, 56(2), 143-174. https://doi.org/10.1080/00074918.2020.1798581.

Oxholm, T., Rivera, C., Schirrman, K., \& Hoverd, W. J. (2021). New Zealand religiouscommunity responses to COVID-19 while under level 4 lockdown. Journal of Religion and Health. https:// doi.org/10.1007/s10943-020-01110-8.

Ozbay, F., Johnson, D. C., Dimoulas, E., Morgan III, C. A., Charney, D., \& Southwick, S. (2007). Social support and resilience to stress: from neurobiology to clinical practice. Psychiatry (Edgmont), 4(5), 35 .

Pargament, K. I. (2013). APA handbook of psychology, religion, and spirituality. American Psychological Association.

Perera, R. A., Mok, C. K., Tsang, O. T., Lv, H., Ko, R. L., Wu, N. C., \& Choi, C. Y. (2020). Serological assays for severe acute respiratory syndrome coronavirus 2 (SARS-CoV-2), March 2020. Eurosurveillance, 25(16), 2000421. https://doi.org/10.2807/1560-7917.ES.2020.25.16.2000421

Pryjmachuk, S., \& Richards, D. A. (2007). Mental health nursing students differ from other nursing students: Some observations from a study on stress and coping. International Journal of Mental Health Nursing, 16(6), 390-402. https://doi.org/10.1111/j.1447-0349.2007.00494.x

Qureshi, W. A., Saud, M., \& Mahmood, Q. K. (2020). Dataset on the fear, preventive behaviour and anxiety disorder during the COVID-19 pandemic in Khyber Pakhtunkhwa, Pakistan. Data in Brief,. https://doi.org/10.1016/j.dib.2020.106579

Salsman, J. M., Brown, T. L., Brechting, E. H., \& Carlson, C. R. (2005). The link between religion and spirituality and psychological adjustment: The mediating role of optimism and social support. Personality and Social Psychology Bulletin, 31(4), 522-535. https://doi.org/10.1177/01461 67204271563

Sarafino, E. P., \& Smith, T. W. (2014). Health psychology: biopsychosocial interactions. John Wiley \& Sons. ISBN: 978-1-119-29948-6

Saud, M., Mashud, M., \& Ida, R. (2020). Usage of social media during the pandemic: Seeking support and awareness about COVID-19 through social media platforms. Journal of Public Affairs. https://doi.org/10.1002/pa.2417

Song, L., \& Lin, N. (2009). Social capital and health inequality: Evidence from Taiwan. Journal of Health and Social Behavior, 50(2), 149-163. https://doi.org/10.1177/002214650905000203

Spiteri, G., Fielding, J., Diercke, M., Campese, C., Enouf, V., Gaymard, A., \& Demina, Y. V. (2020). First cases of coronavirus disease 2019 (COVID-19) in the WHO European Region, 24 January to 21 February 2020. Eurosurveillance, 25(9), 2000178. https://doi.org/10.2807/1560-7917.ES. 2020.25.9.2000178

Tamrat, W., \& Teferra, D. (2020). COVID-19 poses a serious threat to higher education. University WorldNews, 9. 
The Jakarta Post (2020). Retrieved from [https://www.thejakartapost.com/news/2020/03/19/covid-19does-indonesia-need-a-lockdown-it-depends-on-how-you-define-it.html]

Thomas, J., \& Barbato, M. (2020). Positive religious coping and mental health among christians and muslims in response to the COVID-19 pandemic. Religions, 11(10), 498. https://doi.org/10.3390/ rel11100498

Vaccarino, F., Kavan, H., \& Gendall, P. (2011). Spirituality and religion in the lives of New Zealanders. The International Journal of Religion and Spirituality in Society, 1(2), 85-96. https://doi.org/10. 18848/2154-8633/CGP/v01i02/51159

Weiss, R. S. (1974). The Provisions of Social Relationships. In Z. Rubin (Ed.), Doing unto others (pp. 17-26). Prentice Hall.

Wise, T., Zbozinek, T. D., Michelini, G., \& Hagan, C. C. (2020). Changes in risk perception and selfreported protective behaviour during the first week of the COVID-19 pandemic in the United States. Royal Society Open Science, 7, 200742. https://doi.org/10.1098/rsos.200742

World health organization (2019) Coronavirus disease (COVID-19) pandemic. Retrieved from [https:// www.who.int/emergencies/diseases/novel-coronavirus-2019]

Wu, K. K., Chan, S. K., \& Ma, T. M. (2005). Posttraumatic stress, anxiety, and depression in survivors of severe acute respiratory syndrome (SARS). Journal of Traumatic Stress: Official Publication of the International Society for Traumatic Stress Studies, 18(1), 39-42. https://doi.org/10.1002/jts.20004

Wu, K. K., Chan, S. K., \& Yiu, V. F. (2008). Psychometric properties and confirmatory factor analysis of the posttraumatic stress disorder checklist for Chinese survivors of road traffic accidents. East Asian Archives of Psychiatry, 18(4), 144.

Weaver, A. J., Pargament, K. I., Flannelly, K. J., \& Oppenheimer, J. E. (2006). Trends in the scientific study of religion, spirituality, and health: 19652000. Journal of Religion and Health, 45(2), 208214. https://doi.org/10.1007/s10943-006-9011-3

Yee, J., Unger, L., Zadravecz, F., Cariello, P., Seibert, A., Johnson, M. A., \& Fuller, M. J. (2020). Novel coronavirus 2019 (COVID-19): Emergence and implications for emergency care. Journal of the American College of Emergency Physicians Open, 1(2), 63-69. https://doi.org/10.1002/emp2.12034

Zhu, N., Zhang, D., Wang, W., Li, X., Yang, B., Song, J., \& Tan, W. (2020). A novel coronavirus from patients with pneumonia in China, 2019. New England Journal of Medicine, 382, 727-733. https:// doi.org/10.1056/NEJMoa2001017

Publisher's Note Springer Nature remains neutral with regard to jurisdictional claims in published maps and institutional affiliations.

\section{Authors and Affiliations}

\section{Muhammad Saud ${ }^{1}$ (1) $\cdot$ Asia Ashfaq ${ }^{2}$. Ansar Abbas ${ }^{3}$. Septi Ariadi ${ }^{1}$. Qaisar Khalid Mahmood ${ }^{4}$}

1 Department of Sociology, Faculty of Social and Political Science, Universitas Airlangga, Surabaya, Indonesia

2 Department of Humanities and Social Sciences, Bahria University, Islamabad, Pakistan

3 Faculty of Economics and Business, Universitas Airlangga, Surabaya, Indonesia

4 Department of Sociology, International Islamic University, Islamabad, Pakistan 